\title{
JUBILEE DRIVE
}

\section{By ROSE McLAUGHLIN, Indian Head}

On the first Sunday in August we set out to see the crops and countryside, travelling in a square from Indian Head south to Francis, west through Lewvan to Milestone, north into Regina on 6, and then home via No. 1's hardtop. Let's pretend that good crops are cause for unqualified rejoicing, as they were 50 years ago, and call it a jubilee drive.

Our swift prairie summer is almost over. The bloom has gone from the brome, and the delicate blossoms of early summer - rose and harebell, anemone, vetch, and lily and many another-have passed like a wave. Autumn is flooding the landscape, so soon, so soon. It washes over the wheatfields in that indescribable color of half-ripened grain, and it foams along the roadside in a flowering crest of goldenrod and sow thistle, with here and there the soft purple shading of fireweed, aster, and blazing star.

This is along the interlake road through the parkland south of Indian Head, a road made impassable for most of the summer by the phenomenal spring rains. Sloughs lap the newly-built grades in many places, and Dry Lake to the east is probably at its highest in 50 years.

The road swings west, and a puff of dry, dusty wind tells us we are on the open prairie. So do the weedy roadsides. For miles the ragweed stands hedge-high on both sides of us. Saskatchewan, you are a dirty housekeeper! A sowing of brome or sweet clover would soon clean up the ugly weeds.

South of Odessa along the correction line, awareness is heightened by memory, for these are the roads of my childhood. Where now are the bird's eye primroses, the Colorado shooting stars, the lady's slippers, the roses red as the morn? What has become of their winsome grace and gentle individuality? All ground under by the wheels of progress! And has this loss its counterpart in human personality? Maybe not, but this is the year to take stock of such things.
Everywhere the crops are good. In the parkland with its islands and promontories of poplar bluff, field after field is almost ready to swath, but as we travel south the stand grows heavier and later. Wheat stands in closely serried ranks, with the sunlight spilling golden off the shot blade, a sight to thrill the western heart.

The oatfields have a pebbled surface, the wheatfields are embossed, and the barley fields - one recalls that W. O. Mitchell's Kid always says, "the smooth-on barley field". But it has been a bad year for summerfallowing; some of the fallow fields look as if they had been merely threatened, rather than actually cultivated.

Now we are deep down in the Regina plains with their clean, square fields and their beautiful, landscaped farmsteads. The sun shines on brilliant flowerbeds, and there is no trace of livestock anywhere - not even chickens, and certainly not cows. Carnation milk's the best of all - hurrah! Why do our fiction writers not tell us what life is like on these farms, instead of clinging to that dreary literary cliche about farm life being one of poverty and privation with the farmer's wife gnarled with toil, poor soul-no fridge, no fur coat, no TV, and her only possible prospect for a triangle the hired man!

Between Milestone and Regina there are hundreds of acres of shallow sloughs where ducks unlimited swim placidly among the reeds or sun themselves on silty islands. Some sloughs, dried too late for cultivation, are filled with the coppery gold of a million coreopsis flowers, in others the great, showy docks stand as high as a tall man, and "green grow the rushes-o" just every where.

In Regina we stop for a swim in the Wascana pool and a visit to the new museum, but that is a story in itself.

As we take the home stretch along (continued on page 8) 


\section{Uncommon Birds at Spirit Lake}

\section{By WILLIAM ANAKA}

On July 2nd, while investigating a Common Tern nesting colony on a neighbor's field, I had the pleasure of identifying two Black-bellied Plovers. One bird was unmistakeable in the black and white of its full spring plumage. The second one was apparently moulting, be ing dressed mostly in the duller, greyish autumn plumage, but with a very noticeable black belly. I had ample opportunity to observe both as they ran about on the mud flats, and later in flight as they circled about several times before again alighting.

Although noted fairly regularly in spring migration, this is my first summer record. A late spring date for May 30th this year gives rise to the possibility that they may be the same individuals who did not, for some reason, reach their usual summer territory in the Arctic.

The area where I saw the Blackbellied Plover proved to be an excellent spot for many species of shore birds. Originally a cultivated field alongside a shallow creek, it had flooded badly this spring and was left unworked. Shallow sloughs and potholes covered most of the area, creating long stretches of shoreline. The higher ridges were overgrown with weeds of all kinds, providing abundant cover for nests and young birds.

About seventy adult Common Terns were flying about overhead. I was able to locate a nest with two eggs, also three downy young, hiding under dense weeds. On a later visit, July 21st, many immature Common Terns were noted in flight so that most of the adults nested there but the dense growth and protective coloring of the eggs and young made it very difficult to locate either.

Another uncommon shore bird noted there was the Piping Plover. Five or six were seen running about, the pale sand color of their backs contrasting sharply with the dark muddy shore. On my second visit I saw two half-sized young running about with an adult, indicating that iney had nested there.
Many other species of bird life were present: Kildeers, Willets, Marbled Godwits and Wilson's Phalaropes, all protesting my intrusion. A small flock of Greater and Lesser Yellow-legs were noted. A large flock of ducks, mostly Lesser Scaup and Canvasbacks flew off at my arrival. About one hundred Ring-billed Gulls favored a mud bar as a resting place.

Another interesting bird noted this summer was the Hermit Thrushin a heavily wooded area in the sand hills along the south side of Spirit Lake. First attracted by its lovely song, I heard them on July 4th Unable to spend any time searching for it I left, returning several days later. Upon approaching the place where I'd heard the song, I heard an unfamiliar scolding note nearby. After several moments I spotted the bird on a low branch. With the aid of my binoculars I could see quite distinctly the reddish tail, contrasting with the olive-brown back. The habit of occasionally cocking its tail further aided the identification. On several later visits I have always been able to find the bird within a few yards of where I heard it sing. No doubt it was nesting there but I did not have time to thoroughly search the area.

\section{JUBILEE DRIVE}

(Cont. from Page 6)

No. 1 the evening is fragrant with hay and sweet clover and ripening grain. The tawny fields seem to give off light in the purple dusk. "A charm from the skies" rests on St. Joseph's colony, tidy and peaceful in its berth a field or two off the highway.

It is along No. 1 that we note the very latest angle in 50 years of progress - urban folk wealthy enough to move to the country, to make room for the farmers who have become wealthy enough to move to the city! 